\title{
Research on the Central Competence Cultivation of Higher Vocational Tourism Students in the Background of "Belt and Road"
}

\author{
Yu Jie \\ school of management, chongqing electronic engineering vocational college (chongqing 401331)
}

Keywords: Belt and Road; higher vocational tourism students; central competence.

\begin{abstract}
The "Belt and Road " is the abbreviation theme of the "the Silk Road Economic Belt" and the "Marine Silk Road" in the 21st century, which insists that economic cooperation of countries should always be along the positive development and partnership, political mutual trust, economic integration, the community include the culture, interests, fate and responsibility. The "Belt and Road" has provided a great development space for education of China's higher professional profession, which is the need for the development of internationalization education of higher vocational tourism. Under the background of studying how to cultivate the central competence of higher vocational tourism students, tourism can close the gap between students and internationalized talents, improve the students' comprehensive ability and promote the Chongqing pace of internationalization of higher vocational education development in our country, further deepen the reform in the field of higher vocational education, and improve the quality of education and the level of vocational education theory research, enriching the content of the higher vocational education.
\end{abstract}

\section{The review of domestic and foreign research status}

\subsection{The overview of overseas research status}

At the international level, many foreign experts and scholars have paid great attention to the initiative research "One Belt and One Road". Saleh, the director of the center for Asian studies at Cairo university, believes that the concept of the "Chinese dream" is complementary to the idea of "One Belt and One Road". Singapore east Asian institute, he thinks, the silk road on the international stage is not only the Chinese civilization which an effective means of self-confidence and Renaissance, but also a part of China's ancient civilization which relying on the spirit of the rise of great powers. Wu wending, a senior media man in myanmar, believes that the "One Belt and One Road" proposed by China has played a certain role in promoting the peaceful development and common development. In Malaysia's transport minister liao lai in 2015 boao Asia BBS speech said: "One Belt and One Road" area is key factor to the success of the construction of talented person, its outstanding advantage is the talent of creativity and creative thinking". In short, the globalization of the world has provided a good platform for One Belt and One Road strategy. 
In the context of "One Belt and One Road" strategy, students' central competence is highlighted. For the first time, the head of the German federal institute of research, mettens, has proposed the concept of key competencies, which has attracted the attention of many national professional education departments. Germany thinks the key ability, namely central competency is social ability of the individual, is engaged in the foundation of all professional needs to have ability, mainly includes: cooperation ability, communication ability, organization ability, executive ability, learning ability and psychological ability. The central competence of the UK is also called central skills, and the main emphasis is on methods. Britain has identified 21 central competency assessment certification bodies, mainly for the application of digital and information technology to examine the three skills, which skills can be got through in the appraisal certificate. The central competencies of the United States for the workers are mainly embodied in social skills and methods, and the central ability is communicate with each other and to deal with social relations. Although the Australia, Japan, New Zealand and other countries have different emphasis on its central competence and different methods of definition, but they are all attach great importance to the cultivation of central competence of workers.

\subsection{The overview of domestic research status}

The "One Belt and One Road" strategy provides effective guidance and good development opportunities for further promoting the comprehensive reform of education in our country and the international talent training mode. Stand at the height of the international field of vision in higher vocational colleges, updated the internationalization of talents training, cultural exchange and so on. The innovation of higher vocational education "please come in" and "going out" of combining the two development approach, which introduction the international advanced teaching mode and experience. At the same time, in 2015 the national ministry of foreign affairs, the national development and reform commission, the ministry of commerce jointly issued the "push to build the road of silk economic belt and the vision and action of the maritime road of silk in the 21st century, specifically, to strengthen tourism cooperation and expand the scale of tourism. It is tourism awareness month and promotion week activities. This also puts forward new requirements for the cultivation of tourism professionals in higher vocational colleges, so that could build international tourism talents and comprehensively improve students' central competence.

The cultivation of students' central competence in higher vocational colleges is a complicated system engineering. Zhang, yun-chang zhang (2013) study suggests that the central competence of tourism specialty mainly includes: interpersonal communication ability, cooperation and organization ability, expression and communication ability, service ability, innovation ability, bear ability, entrepreneurship, etc. Miss wu (2016) research thinks, "One Belt and One Road" tourism vision provides a new perspective for the development of tourism industry in China, higher vocational colleges as well as tourist class put forward the new direction of talent cultivation. Wu (2016) study, education internationalization is the trend of the world education development, also is the inevitable choice of internationalized talent cultivation, its essence is the internationalization of talent education internationalization which improve the central competence of students in higher vocational colleges and the internationalization of cultivating high quality talents for the country.

In conclusion, combine the three studies including scholars, central competencies and even all the travel way to the area of professional central ability on the points above, thus "area" under the background of higher vocational tourism class students study has certain methods of cultivating the central of value competence. 


\section{The analysis of central competence of tourism students in higher vocational colleges}

\subsection{The higher vocational tourism major}

According to the vocational education and adult education department of the People's Republic of China, the ministry of education in 2017 released by the tourism specialty including that: tourism management, tour guide, travel agency management, scenic area development and management, hotel management, leisure and other professional services and management.

\subsection{The understanding of central competence}

In 1990, prahalad and hamel first put forward the concept of " central competencies" in the harvard business review. central competence refers to the company's main ability, even if the company is in the dominant position in the competition, which is a kind of ability that other competitors are difficult to achieve or cannot have. The author thinks that central competence is the key to success, when the labor organization or career changes. The central competence of workers still play a role, which different from others of the more difficult to replicate ability, it has the characteristics of portability, universality and instrumental, plays a decisive role in terms of employment.

\subsection{To explore the central competence content of students majoring in tourism}

The central competence of tourism professional students should be specific to this professional student ability, difficult to copy and imitate other professional students, the ability can be gained through the students' learning and practice, which lead to enhance the competitiveness of the students in employment. The central competence of tourist class students mainly includes the professional spirit, professional and comprehensive qualities, professional skills, professional development ability, etc. In addition, specific competence include: bear ability, interpersonal skills, language ability, service and management ability, cooperation and organization ability, expression and communication ability, innovation and entrepreneurship and career planning ability, etc.

\section{The analysis of the current situation of tourism professionals' demand in ChongQing in the context of "One Belt and One Road"}

\subsection{With the number of tourists has increased while the demand for tourism professionals has increased}

In 2009 the State Council issued "the opinion on accelerating the development of tourism", proposed to build tourism into a strategic pillar industry of national economy and make people more satisfied modern service industry, this is the development direction of tourism industry in the future. According to the world tourism organization, China will become the world's largest tourist host country and the fourth largest source of tourists in the world until 2020. With the promotion of "One Belt and One Road" strategy, China's tourism connectivity and infrastructure improvement have greatly broadened the scope of inbound tourism. In addition, under the background of signed a series of cooperation, including visa facilitation measures, for the personnel exchanges and communication between countries and regions along the provides a good platform, the immigration presents the geometric type growth and the demand for tourism professionals also gradually increased. According to the statistics of ChongQing education committee, there are 72 colleges and universities in ChongQing, and more than 160 secondary vocational schools. At the end of 2017, 
according to chongqing tourism administration website, there are 224 a-level scenic spots, 206 star hotels, 38 cruise ships and 588 travel agencies. To sum up, colleges and universities of higher education and secondary vocational schools have more than half of the colleges and universities that offer tourism. However, the number of students in the class is small, and the shortage of students is still large. In 2017, the number of inbound tourists reached about 139.48 million, compared to an increase of $0.8 \%$ over the previous year. Xi jinping visited ChongQing in early 2016 general secretary pointed out: " ChongQing is an important strategic fulcrum of the western development, in the Yangtze river economic belt of the join point, in the national regional development and opening-up pattern has a unique and important role", under the background of the ChongQing tourism foreseeable broad prospects for professional development.

3.2 The international exchanges have deepened and the needs of tourism professionals have become more specialized

According to the data report of Chinese outbound tourism in 2017, Chinese citizens outbound tourism break through 130 million person-time year by year growth of $7.0 \%$, China's international tourism spending of $\$ 115.29$ billion which increased by 5\% and China has to keep the world's largest outbound tourism inbound tourists for many years. Due to the history between the different culture, language, customs, etc, which will require more specialized tourist talents engaged in overseas travel related activities, and through tourism personnel exchanges and publicity in order to drive the national economic and trade exchanges and communication, tourism personnel to deal with the problem of comprehensive ability and professional level is particularly important.

\subsection{The diversity of communication among countries has put forward new requirements for the improvement of central competence of tourism professionals}

The "One Belt and One Road" strategy is not only a cooperation among countries but also a comprehensive exchange of economy, which including trade, science, technology, ecology and human resources. Such activities as international folklore tourism promotion activities and joint protection work for the world heritage. All of the central competence of tourism professionals put forward the higher request and the tourist class professional knowledge, which more need to have a high level of intercultural sensitivity, strong language and communication skills.

4. The effective strategy research of the core competence cultivation of ChongQing vocational college students in the background of "One Belt and One Road"

\subsection{Innovate teaching mode and constantly update the talent training program}

First of all, through collecting foreign teaching process, which draw lessons from foreign advanced teaching methods and educational philosophy. The competition is the necessary knowledge, quality and central competence of the international tourism talent; secondly, promote education diplomacy and BBS diplomacy attract international experts and foreign students to enhance the communication between teachers and students of the university and foreign friends. In addition, strengthen the cultivation of students' practical ability, carry out teaching mode of interaction, XueGang through practice to encourage students in his spare time. The foreign friends more communication and exchanges with foreign friends, understand foreign culture, customs and habits, enhance the students' communication ability, cooperation ability, and ability to solve practical problems, etc.

Under the background of economic globalization, the tourism major of higher vocational 
colleges needs to reconstruct the curriculum system. On the one hand, according to the actual situation of the school, to the internationalization of tourism professional teaching material of appropriate adaptation, et.al., combined with our teaching material, draw lessons from foreign teaching material's new way of thinking, which really with international standards; Secondly, in order to increase the total learning of foreign language courses, it is of great help to master a foreign language for the future career development. Since this skill requires long-term accumulation, it is difficult for others to replicate in a short time. So schools should actively introduce foreign students, increase the proportion of teachers and creating foreign language community, increase the students the opportunity to practice spoken language and improve the students' foreign language communication skills.

\subsection{Improve the teaching staff and build a double team}

First, encourage the teachers to study abroad for further study, draw lessons from foreign advanced teaching mode and accumulate teaching experience gradually. In addition, enhance the school teachers and improve teachers' comprehensive ability; Secondly, teachers should be encouraged to adopt the whole foreign language teaching mode, actively participate in various international conferences and exchanges specially, acquire the latest new skills and knowledge, and improve the business level of teachers.

\subsection{Focus on students' social, service and management skills}

Tourism is a very service industry, so the ability of interpersonal communication and language communication is an indispensable central competence for students in higher vocational education. Part of the hotel management students with poor interpersonal skills, language expression force is not strong, which always lead a frequent job-hopping in the end or leave the hotel industry. Besides strengthening students' practical ability and theoretical knowledge, the enhancement of central competence also needs to pay attention to the cultivation of students' social, service and management skills. First, the school needs to strengthen international cooperation so as to provide smooth and natural services to foreign tourists. Secondly, the school should carry out the teaching of the theory of service and management, and combine the school with practice skills training. In the process of personnel training to strengthen the student work in the service and management field or with work practice, from the student's fitness and the ease of school management, the internship units should not be too far from the school, internship time also is not necessarily the whole semester participate in practice, which can make full use of the national legal holidays and weekends. The students take turns to scenic areas or hotel and other travel companies act as free helper, enterprise only to give students a certain traffic and living subsidies. Each semester in practice time to ensure that at least two weeks to travel companies with them or with work practice, this can also be converted into two weeks of practice credits, included in the graduation total credit, so as to improve students' enthusiasm to participate in practice. For the aim to give students a month wage subsidies, the school could contact fixed a tourism enterprises to enterprise practice half a semester, this not only ensure the freshness of internship students but also guaranteed the enterprise fixed number of staff available. Because the student entered the enterprise a lot of behavior not have a classical standard, and most students subconscious think they haven't graduated, should not participate in the high strength work, and therefore usually half of the field is easily accepted by students. In the arrangement of practical time, the first academic year is more basic course and the task is unfavorable arrangement. From the point of view of knowledge comprehensive, appropriate from the third semester winter vacation until the end of the fifth semester of school, roughly time is from February to November, because the student is take turns to go, so students about 5 months 
on-the-job practice time. After November, students will be able to contact the internship to prevent students from missing out on their favorite year-end recruitment conference.

\subsection{Continuously improves students' ability to innovate their own business and career planning}

As the saying goes, "interest is the best teacher", so it is an important prerequisite to study hard to guide students' interest in major. The school should carry out academic lectures to broaden students' horizon regularly. Furthermore, actively carry out various professional competition activities, operate the skill competition, arouse the enthusiasm of the students and improve the professional skill level. We will actively carry out innovation, entrepreneurship and career planning guidance, so that students can make the transition from the small society of the school to the big society, so as to avoid the uncertain prospects of students in school and graduation. With the popularization of education, the employment pressure of college students is increasing and the competition for good jobs is becoming more and more fiercely. For higher vocational college students, their degree is inferior to undergraduate and graduate students, this is even more added their employment crisis for some students and parents who think that read a specialized subject even as early as possible go home open a shop business. So, have a clear plan for the future of students, students during the period of school can offer certain site support and technical guidance, the school can make use of catering training rooms help students open the coffee shop, bar, specialty restaurants, which can take advantage of tourism training rooms even open a travel agency, etc.. At last, let the creative ability of students to stand out and vocational education to explore the road of reform and innovation.

All the way along the "construction is the development and change of the CPC central committee on the basis of global, as a whole to promote the international and domestic two overall situation to make major moves. In recent years, the higher vocational tourism class students under the background of central ability need global economy's biggest engines training and study, which has a potential to become widely employed as a mutual director in the future.

\section{References}

[1] zhang lijuan, wang meiping. Strategies and approaches for the cultivation of core competence of tourism vocational students [J]. Education and career, 2014,(29):109-110.

[2] liang xiangping. Teaching reform of higher vocational tourism majors based on vocational core competence [J]. Journal of education college of nanchong, 2016,(4):85-86.

[3] su jianjun, jindi. Reconstruction of tourism management professional curriculum system: perspective of post capability [J]. High education BBS, 2017,(2):23-26. 